\title{
The intact postsynaptic protein neurogranin is reduced in brain tissue from patients with familial and sporadic Alzheimer's disease
}

\author{
Hlin Kvartsberg ${ }^{1} \oplus$. Tammaryn Lashley 2,3 . Christina E. Murray ${ }^{2,4}$. Gunnar Brinkmalm ${ }^{1,5} \cdot$ Nicholas C. Cullen $^{1}$. \\ Kina Höglund ${ }^{1,5,6} \cdot$ Henrik Zetterberg ${ }^{1,3,4,5} \cdot$ Kaj Blennow $^{1,5} \cdot$ Erik Portelius $^{1,5}$
}

Received: 6 August 2018 / Revised: 14 September 2018 / Accepted: 14 September 2018 / Published online: 22 September 2018

(c) The Author(s) 2018

\begin{abstract}
Synaptic degeneration and neuronal loss are early events in Alzheimer's disease (AD), occurring long before symptom onset, thus making synaptic biomarkers relevant for enabling early diagnosis. The postsynaptic protein neurogranin $(\mathrm{Ng})$ is a cerebrospinal fluid (CSF) biomarker for $\mathrm{AD}$, also in the prodromal phase. Here we tested the hypothesis that during $\mathrm{AD}$ neurodegeneration, processing of full-length $\mathrm{Ng}$ into endogenous peptides in the brain is increased. We characterized $\mathrm{Ng}$ in post-mortem brain tissue and investigated the levels of endogenous $\mathrm{Ng}$ peptides in relation to full-length protein in brain tissue of patients with sporadic (SAD) and familial Alzheimer's disease (fAD), healthy controls and individuals who were cognitively unaffected but amyloid-positive (CU-AP) in two different brain regions. Brain tissue from parietal cortex [sAD $(n=10)$ and age-matched controls $(n=10)]$ and temporal cortex [sAD $(n=9)$, fAD $(n=10)$, CU-AP $(n=13)$ and controls $(n=9)$ ] were included and all the samples were analyzed by three different methods. Using high-resolution mass spectrometry, 39 endogenous $\mathrm{Ng}$ peptides were identified while full-length $\mathrm{Ng}$ was found to be modified including disulfide bridges or glutathione. In SAD parietal cortex, the ratio of peptide-to-total full-length $\mathrm{Ng}$ was significantly increased for eight endogenous $\mathrm{Ng}$ peptides compared to controls. In the temporal cortex, several of the peptide-to-total full-length $\mathrm{Ng}$ ratios were increased in both $\mathrm{SAD}$ and fAD cases compared to controls and CU-AP. This finding was confirmed by western blot, which mainly detects full-length $\mathrm{Ng}$, and enzyme-linked immunosorbent assay, most likely detecting a mix of peptides and full-length $\mathrm{Ng}$. In addition, $\mathrm{Ng}$ was significantly associated with the degree of amyloid and tau pathology. These results suggest that processing of $\mathrm{Ng}$ into peptides is increased in $\mathrm{AD}$ brain tissue, which may reflect the ongoing synaptic degeneration, and which is also mirrored as increased levels of $\mathrm{Ng}$ peptides in CSF.
\end{abstract}

Keywords Neurogranin $\cdot$ Alzheimer's disease $\cdot$ Brain tissue $\cdot$ Familial Alzheimer's disease $\cdot$ Mass spectrometry

\section{Introduction}

Electronic supplementary material The online version of this article (https://doi.org/10.1007/s00401-018-1910-3) contains supplementary material, which is available to authorized users.

Hlin Kvartsberg

hlin.kvartsberg@neuro.gu.se

1 Department of Psychiatry and Neurochemistry, Institute of Neuroscience and Physiology, The Sahlgrenska Academy at the University of Gothenburg, Sahlgrenska University Hospital/Mölndal, S-431 80 Mölndal, Sweden

2 Queen Square Brain Bank for Neurological Disorders, Department of Movement Disorders, UCL Institute of Neurology, London, UK
Alzheimer's disease (AD) is the most common form of dementia, affecting tens of millions of people worldwide and with numbers increasing each year [1]. AD is a neurodegenerative disorder characterized by certain neuropathological

3 Department of Neurodegenerative Disease, UCL Institute of Neurology, Queen Square, London, UK

4 UK Dementia Research Institute at UCL, London, UK

5 Clinical Neurochemistry Laboratory, Sahlgrenska University Hospital, Mölndal, Sweden

6 Department of Neurobiology, Care Sciences and Society, Center for Alzheimer Disease Research, Neurogeriatrics Division, Karolinska Institutet, Novum, Huddinge, Stockholm, Sweden 
hallmarks in the brain including extracellular plaques consisting of amyloid $\beta$ (A $\beta$ ) peptides and intracellular neurofibrillary tangles composed of hyperphosphorylated tau (p-tau) protein [9]. Most AD patients have no known cause and are termed sporadic (sAD), but around $1 \%$ are due to autosomal dominant mutations in genes related to amyloid metabolism, e.g., APP, PSEN1 and PSEN2, causing the hereditary form called familial AD (fAD) $[6,13,55]$. In contrast to sporadic $\mathrm{AD}$, which usually presents after the age of 65 , the onset of fAD is generally much earlier.

Even at early stages of the disease, dysfunction and loss of synapses are directly linked to cognitive symptoms such as memory disturbances and are thought to occur earlier than neuronal loss [18]. In fact, the degree of dementia has been found to be more associated with synaptic loss compared to amyloid plaques and tangles $[8,16,37,52,58]$. In addition, studies using immunohistochemistry and immunoelectronmicroscopy also suggest that synaptic loss occur without clear relation to plaque pathology [8,36]. Synaptic loss is especially pronounced in certain areas of the brain such as the hippocampus $[52,53]$. Consequently, synaptic proteins have the potential to be highly suited as biomarkers for early $\mathrm{AD}$ diagnosis in addition to monitoring disease progression and evaluating novel disease-modifying therapeutics.

Neurogranin $(\mathrm{Ng})$ is a 78 -amino acid-long postsynaptic protein that plays a critical role in long-term potentiation (LTP). LTP is thought to be crucial for the formation of long-term memories, through regulating the concentration of calmodulin by responding to intracellular calcium levels following neuronal excitation $[4,20,25,63] . \mathrm{Ng}$ is able to bind to calmodulin via an IQ motif (amino acid 33-46) which is well conserved among other calmodulin-binding proteins, such as the pre-synaptic protein growth-associated protein 43 (GAP-43). In the brain, $\mathrm{Ng}$ expression is localized to dendritic spines of neurons in the amygdala, hippocampus, cerebral cortex, and other associative cortical areas [10, 20]. In mice, both Ng mRNA and protein concentrations in the hippocampus decrease with age and are related to central nervous system (CNS) dysfunction [41]. In addition, knockdown models display reduced LTP as well as impaired cognition [23] while upregulation improves LTP along with cognitive performance [65].

It is well established that cerebrospinal fluid (CSF) $\mathrm{Ng}$ is increased in SAD compared to healthy controls $[17,24$, $28,30,32,33,45,46]$. Increased CSF Ng concentrations can also be used to distinguish patients with mild cognitive impairment (MCI) that will convert to SAD from those that remain stable [30, 32, 38, 46]. However, data from brain tissue indicate a decrease of $\mathrm{Ng}$ concentrations in both the frontal cortex [15, 49], parietal cortex [49] and hippocampus [15]. We have previously shown that $\mathrm{Ng}$ in brain tissue is present both as intact full-length protein and as a variety of endogenous C-terminal peptides [32]. Therefore, we aimed to characterize $\mathrm{Ng}$ in brain tissue and to quantify full-length $\mathrm{Ng}$ and $\mathrm{Ng}$ peptides in post-mortem brain tissue of patients with $\mathrm{SAD}$, fAD, healthy controls as well as cognitively unaffected amyloid-positive (CU-AP) individuals, which have neuropathological changes beyond normal levels for their age. We also tested the hypothesis that during the neurodegenerative process of $\mathrm{AD}$, higher amounts of endogenous $\mathrm{Ng}$ peptides are generated in the brain through processing of full-length $\mathrm{Ng}$ compared to brains without AD neuropathology. Here, we present results of $\mathrm{Ng}$ in post-mortem brain tissue from two different cohorts measured by three independent methods, showing that full-length $\mathrm{Ng}$ in the brain has post-translational modifications (PTM) and that there is a shift from full-length $\mathrm{Ng}$ to peptides in both $\mathrm{SAD}$ and fAD compared to CU-AP and controls.

\section{Materials and methods}

\section{Individuals included in study 1}

Post-mortem brain tissue samples from the superior parietal gyrus of individuals with $\operatorname{SAD}(n=10)$ and healthy controls $(n=10)$, obtained from the Netherlands Brain Bank, were stored at $-80{ }^{\circ} \mathrm{C}$ pending biochemical analysis. All sAD patients fulfilled Braak stages V or VI and the controls fulfilled Braak stages 0 or I in accordance with the Braak and Braak criteria [11]. As this material was collected and scored before 2012, the 2012 National Institute on Ageing (NIA) and the Alzheimer's Association (AA) guidelines for neuropathologic assessment of AD [26] were not used. Controls were assessed by retrospective telephone interviews with the next of kin, to assure that they had no cognitive symptoms. Demographics of the patients included in study 1 are shown in Table 1 and full demographics are detailed in Online Resource 1.

\section{Individuals included in study 2}

Post-mortem brain samples from temporal cortex of patients with $\operatorname{sAD}(n=9)$, fAD $(n=10), \mathrm{CU}-\mathrm{AP}(n=13)$ and healthy controls $(n=9)$ were obtained from the Queen Square Brain Bank, UCL Institute of Neurology, London, UK. AD patients fulfilled the clinical NINCDS criteria for probable AD [39] and met the 2012 NIA-AA guidelines for neuropathologic assessment of AD [26]. Thal phases were determined as a measure of the spread $\mathrm{A} \beta$ pathology throughout the brain as described [60]. Braak stages were scored according to the Braak and Braak criteria [11]. Braak tau neurofibrillary tangle staging (PHF-1) and the Consortium to Establish a Registry for AD (CERAD) neuritic plaque score (thioflavin stain) were used to classify AD neuropathology into four groups as described previously (Hyman et al. 2012): no (or 
Table 1 Demographics and clinical characteristics of subjects included in study 1 and 2

\begin{tabular}{|c|c|c|c|c|}
\hline & $\mathrm{sAD}$ & Control & fAD & CU-AP \\
\hline Study 1 & $n=10$ & $n=10$ & & \\
\hline Gender, $n$, female/male ( $\%$ female) & $6 / 4(60)$ & $6 / 4(60)$ & & \\
\hline Age at death & 77 [72-79] & $72.5[69.5-80.5]$ & & \\
\hline Post-mortem delay, (h) & $5[4-6]$ & $7[6-7]$ & & \\
\hline Braak stage $0-\mathrm{I} / \mathrm{II}-\mathrm{IV} / \mathrm{V}-\mathrm{VI}$ & $0 / 0 / 10$ & $10 / 0 / 0$ & & \\
\hline Study 2 & $n=9$ & $n=9$ & $n=10$ & $n=13$ \\
\hline Gender, $n$, female/male ( $\%$ female) & $3 / 6(33)$ & $5 / 4(56)$ & $6 / 4(60)$ & $9 / 4(69)$ \\
\hline Age at onset & $60[52-69]^{\S}$ & $\mathrm{n} / \mathrm{a}$ & $43[36-53]$ & $\mathrm{n} / \mathrm{a}$ \\
\hline Duration, (years) & $11.5[10-15]$ & $\mathrm{n} / \mathrm{a}$ & $9[5-13]$ & $\mathrm{n} / \mathrm{a}$ \\
\hline Age at death & $72[66-80]^{*}$ & $82[70-85]^{\alpha}$ & $54[46-65]^{\#}$ & 88 [84-91] \\
\hline Post-mortem delay, (h) & 65 [47-92] & $75[40-86]$ & $38[26-65]^{\# \#}$ & 78 [39-102] \\
\hline Brain weight, (g) & $1116[1009-1244]^{\dagger}$ & $1330[1250-1474]$ & $1108[880-1320]^{\infty \infty \alpha}$ & $1264[1192-1421]$ \\
\hline Braak stage $0-\mathrm{I} / \mathrm{II}-\mathrm{IV} / \mathrm{V}-\mathrm{VI}$ & $0 / 0 / 9$ & $7 / 2 / 0$ & $0 / 0 / 10$ & $1 / 12 / 0$ \\
\hline Thal stage $0-1 / 2-4 / 5-6$ & $0 / 0 / 9$ & $8 / 1 / 0$ & $0 / 0 / 10$ & $1 / 9 / 3$ \\
\hline CERAD score $0 / \mathrm{A} / \mathrm{B} / \mathrm{C}$ & $0 / 0 / 0 / 9$ & $6 / 2 / 0 / 1$ & $0 / 0 / 0 / 10$ & $2 / 6 / 5$ \\
\hline $\mathrm{ABC}$ score, minimum-maximum & A3B3C3 & $\begin{array}{l}\text { A0B0C0-A2B1C1/ } \\
\text { A1B2C1 }\end{array}$ & A3B3C3 & $\mathrm{A} 1 \mathrm{~B} 2 \mathrm{C} 2-\mathrm{A} 3 \mathrm{~B} 2 \mathrm{C} 2$ \\
\hline Mutation, $P S N 1 / A P P$ & & & $8 / 2$ & \\
\hline ELISA, (ng/mg) total protein & $253.9[137-346.2]$ & $398.1[305.9-631.8]$ & $291.2[169.9-363.3]^{\# \# \#}$ & $518.7[440.1-741.7]$ \\
\hline
\end{tabular}

Differences between groups in study 1 were assessed using Mann-Whitney $U$ test. Comparisons between groups in study 2 were performed using Kruskal-Wallis test with data adjusted for post-mortem delay, followed by pairwise Mann-Whitney $U$ tests if significant. The data are presented as median and [interquartile range]

${ }_{\mathrm{S}}^{\S} \mathrm{AD}$ vs fAD $p=0.003 ;{ }^{*} \mathrm{SAD}$ vs CU-AP $p=0.033 ;{ }^{\dagger} \mathrm{SAD}$ vs controls $p=0.013 ;{ }^{\text {a }} \mathrm{fAD}$ vs control $p=0.032 ;{ }^{\infty} \mathrm{fAD}$ vs control $p=0.025 ;{ }^{\#} \mathrm{fAD}$ vs CU-AP $p<0.0001 ;{ }^{\#}$ fAD vs CU-AP $p=0.029 ; " \# \#$ fAD vs CU-AP $p=0.017$

negligible) $\mathrm{AD}$ neuropathology (0), low level $\mathrm{AD}(\mathrm{A})$, intermediate-level $\mathrm{AD}(\mathrm{B})$, and high-level $\mathrm{AD}(\mathrm{C})$. In addition, an $\mathrm{ABC}$ score that incorporates histopathologic assessments of $\mathrm{A} \beta$ deposits (A), staging of neurofibrillary tangles (B) and scoring of neuritic plaques (C) was calculated as described previously [42]. fAD patients had mutations in either PSEN1 $(n=8)$ or APP $(n=2)$ genes. The PSEN1 mutations included R278I, E120K, A434T+T291A, I202F, E184D, S132A, and intron 4 and all APP mutations were V717I. Due to the numbers of different mutations in the fAD group the cases were grouped together for analysis. The cognitively normal status of the control cases used in this study was confirmed from assessment forms received at brain donation. The assessment forms are completed by both the person donating their brain and/or by relatives or next of kin. We also have access to all the medical records that were summarized by a neurologist. The CU-AP patients were cases who had died from acute cardiac or malignant disease, without history of dementia, or psychiatric or neurological diseases where the autopsy examination revealed AD-like pathology beyond what can be considered normal for age. A summary of case demographics of the cases included in study 2 is shown in Table 1 , with full demographics detailed in Online Resource 1.

Both studies were conducted according to the provisions of the Helsinki Declaration. All subjects gave written informed consent for the use of their clinical data for research purposes, and the local Ethical Committees at the respective university approved each study.

\section{Generation of anti-Ng antibodies}

The monoclonal anti- $\mathrm{Ng}$ antibodies $\mathrm{Ng} 2$ and $\mathrm{Ng} 3$ have been described previously [32], while $\mathrm{Ng} 36$ was generated using the same protocol, but with KLH-conjugated peptide Ng63-75 (Caslo ApS Denmark) as immunogen. All of the antibodies were purified using a protein $\mathrm{G}$ column (GE Healthcare).

\section{Homogenization of brain tissue for western blot, mass spectrometric analysis and immunoassay}

Brain tissue $(100 \pm 10 \mathrm{mg})$ (superior parietal gyrus or temporal cortex) were homogenized on ice in Tris-buffered saline (TBS) (1:5 weight:volume ratio) containing complete protease inhibitor (Roche Diagnostics GmbH, Mannheim, Germany). The homogenized tissue was further diluted in TBS (1:5) followed by centrifugation at $31,000 \mathrm{~g}$ at $+4{ }^{\circ} \mathrm{C}$ for $1 \mathrm{~h}$. The supernatant (TBS fraction) was removed and stored at $-80{ }^{\circ} \mathrm{C}$ pending analysis. Total protein concentration of 
all homogenized samples was determined using the DCTM Protein Assay (Bio-Rad Laboratories) according to the manufacturer's instructions. The samples were diluted in PBS (1:40) prior to immunoprecipitation.

\section{Hybrid immunoaffinity-mass spectrometry}

$4 \mu \mathrm{g}$ of the anti- $\mathrm{Ng}$ antibodies $\mathrm{Ng} 2$ and $\mathrm{Ng} 3$ were separately added to $25 \mu \mathrm{L}$ M-280 Dynabeads (Sheep anti-mouse $\mathrm{IgG}$, Invitrogen) according to the manufacturer's product description and cross-linked as previously described [12]. $\mathrm{Ng}$ 2- and Ng3-coated beads were used for immunoprecipitation of brain extracts to which Tween 20 (final concentration $0.025 \%$ ) was added and incubated. Beads and samples were transferred to a KingFisher magnetic particle processor (polypropylene tubes, Thermo Scientific, Waltham, MA, USA) for automatic washing and elution of full-length and $\mathrm{Ng}$ peptides. Eluted $\mathrm{Ng}$ was collected and dried in a vacuum centrifuge and re-dissolved in $5 \mu \mathrm{L} 0.1 \%$ formic acid (FA) in $20 \%$ acetonitrile (ACN) and subsequently analyzed using a Bruker Daltonics UltraFleXtreme matrix assisted laser desorption/ionization time-of-flight/time-of-flight (MALDI TOF/TOF) mass spectrometer (Bruker Daltonics, Bremen, Germany) or high-resolution tandem mass spectrometry (MS/MS) using a Dionex Ultimate 3000 nanoflow liquid chromatography (LC) system (Thermo Fisher Scientific). A detailed description about LC-MS/MS and database searches that were performed can be found in Online Resource 2. All solvents used were of HPLC grade. In both studies in which MALDI TOF/TOF MS was used, the custom Ng peptide RKKIKSGERGRKGPGPGGPGGAGVARGGAGGGP (corresponding to $\mathrm{Ng} 43-75)$, with all glycines fully labeled with ${ }^{13} \mathrm{C}$ (theoretical molecular mass: $3011 \mathrm{Da}$; CASLO, Lyngby, Denmark), was added to the tissue homogenate during sample preparation and was used as an internal standard. Samples were analyzed blinded (that is, without knowledge of clinical diagnosis). All calculated concentrations were normalized to total protein concentration of the sample.

\section{Reduction and alkylation of full-length neurogranin}

Full-length $\mathrm{Ng}$ from brain tissue was first purified according to the hybrid immunoaffinity-mass spectrometry (HI-MS) procedure. After vacuum centrifugation, the samples were dissolved in $5 \mu \mathrm{L} 20 \% \mathrm{ACN}$ and vortexed for $1 \mathrm{~h}$. Thereafter $15 \mu \mathrm{L} 50 \mathrm{mM} \mathrm{NH}_{4} \mathrm{HCO}_{3}$ was added and samples were vortexed. Then $20 \mu \mathrm{L} 10 \mathrm{mM}$ dithiothreitol (DTT) in $50 \mathrm{mM}$ $\mathrm{NH}_{4} \mathrm{HCO}_{3}$ was added to the samples followed by a 3-min incubation at $+90{ }^{\circ} \mathrm{C}$. The samples were allowed to cool to room temperature for $30 \mathrm{~min}$ after which $40 \mu \mathrm{L} 10 \mathrm{mM}$ iodoacetamide in $50 \mathrm{mM} \mathrm{NH} \mathrm{HCO}_{3}$ was added. Samples were then incubated at room temperature in the dark for 30 min after which they were dried in a vacuum centrifuge and stored at $-80{ }^{\circ} \mathrm{C}$ pending MS analysis. Negative control samples were only incubated $3 \mathrm{~min}$ at $90{ }^{\circ} \mathrm{C}$ without the addition of DTT prior to drying in a vacuum centrifuge.

\section{Western blot}

$1 \mu \mathrm{g}$ of total protein was mixed with XT sample buffer (BioRad Laboratories) and XT reducing agent (Bio-Rad Laboratories) before boiling $5 \mathrm{~min}$ at $95^{\circ} \mathrm{C}$. Samples and full-length recombinant calibrator $\mathrm{Ng}-\mathrm{Myc}-\mathrm{DKK}$ fusion protein (Origene, product no TP301209) ranging from 1.56 to $25 \mathrm{ng}$ were electrophoresed on $12 \%$ Criterion XT Bis-Tris Gel using the Criterion cell tank (Bio-Rad Laboratories). The proteins were transferred to $0.2 \mu \mathrm{m}$ nitrocellulose membrane (Amersham), using the semi-dry blotting technique. Blocking was performed for $1 \mathrm{~h}$ at room temperature using 5\% blotting-grade blocker (Bio-Rad Laboratories) in phosphate-buffered saline (0.01 M phosphate buffer, $0.14 \mathrm{M} \mathrm{NaCl}$, pH 7.4; PBS) containing Tween 20 (Bio-Rad Laboratories, final concentration $0.05 \%$; PBS-Tween). Incubations with the monoclonal Ng36 diluted 1:1250 in 1\% blotting-grade blocker in PBS-Tween or no primary antibody (negative control) was performed overnight at $+4{ }^{\circ} \mathrm{C}$. The membranes were washed for $3 \times 10 \mathrm{~min}$ in PBS-Tween and then incubated for $1 \mathrm{~h}$ at room temperature with goat anti-mouse $\mathrm{IgG}(\mathrm{H}+\mathrm{L})$ poly-HRP secondary antibody HRP $(0.5 \mathrm{mg} / \mathrm{mL})$ (Thermo Fisher Scientific) diluted 1:15,000 in PBS-Tween containing 1\% bovine serum albumin (BSA). Following $3 \times 10$ min washes in PBS-Tween, the membranes were developed for 2 min with ECL Select ${ }^{\mathrm{TM}}$ Western Blotting Detection Reagent (GE Healthcare) according to the manufacturer's instructions. The emitted signal was detected by a Fujifilm LAS-3000 System (FUJIFILM Corporation) and protein bands were quantified using ImageJ software version 1.51j8 (Rasband, WS, ImageJ; National Institutes of Health, Bethesda, MD, http://rsb.info.nih.gov/ij). SOFTmax ${ }^{\circledR}$ Pro 4.0 (Molecular Devices Corporation, Sunnyvale, CA, USA) and a fitted four-parameter logistic model calibration curve were used to quantify $\mathrm{Ng}$ concentration of samples. Samples that were below the lowest point of the standard curve but still visible were given a value of half the lowest concentration, i.e., $0.78 \mathrm{ng}$. A standard curve, negative controls, quality control sample of brain tissue homogenate and molecular size marker SeeBlue Plus2 Pre-stained protein standard (Thermo Fisher Scientific) was included on all gels.

\section{Sandwich ELISA method of $\mathrm{Ng}$}

$\mathrm{Ng} 36$ was used as a capturing antibody and was coated on Nunc maxisorp 96-well microtiter plates at a final concentration of $0.5 \mu \mathrm{g} / \mathrm{mL}(100 \mu \mathrm{L} /$ well $)$ in $\mathrm{NH}_{4} \mathrm{HCO}_{3}$ buffer, pH 9.6, overnight at $+4{ }^{\circ} \mathrm{C}$. After washing with PBS-Tween $4 \times 350 \mu \mathrm{L}$, the remaining protein binding sites were blocked with $1 \%$ BSA in PBS-Tween for $1 \mathrm{~h}$ at 
room temperature $(250 \mu \mathrm{L} /$ well $)$. Thereafter, plates were washed with PBS-Tween $4 \times 350 \mu \mathrm{L}$. Full-length GSTtagged recombinant $\mathrm{Ng}$ calibrators with concentrations ranging between 7 and $940 \mathrm{pg} / \mathrm{mL}$, blanks and TBS brain samples (diluted 1:10,000, $100 \mu \mathrm{L} /$ well) were incubated in duplicate for $3 \mathrm{~h}$ at room temperature, $350 \mathrm{rpm}$, followed by washing with $4 \times 350 \mu \mathrm{L}$ PBS-Tween. Detector antibody, biotinylated $\mathrm{Ng} 2$ final concentration $0.5 \mu \mathrm{g} / \mathrm{mL}$ (100 $\mu \mathrm{L} /$ well) in $1 \%$ BSA PBS-Tween, was added followed by incubation for $1 \mathrm{~h}$ at room temperature and washing with $4 \times 350 \mu$ L PBS-Tween. Enhanced streptavidin-HRP (KemEnTech) was diluted according to the manufacturer's instructions and added $(100 \mu \mathrm{L} /$ well $)$ and incubated $30 \mathrm{~min}$ at room temperature. After washing with $4 \times 350 \mu \mathrm{L}$ PBSTween, TMB substrate (BioRad Laboratories, $100 \mu \mathrm{L} /$ well) was added to produce the color reaction. After $20 \mathrm{~min}$ in darkness, the reaction was stopped by addition of $100 \mu \mathrm{L}$ of $0.2 \mathrm{M} \mathrm{H}_{2} \mathrm{SO}_{4}$, and following 1 min incubation at room temperature, $450 \mathrm{rpm}$, the absorbance was measured at $450 \mathrm{~nm}$ (reference wavelength $650 \mathrm{~nm}$ ) using an ELISA plate reader (Sunrise, Tecan Trading AG, Switzerland). A fitted four-parameter logistic model was used as the calibration curve and the blank was included as zero concentration of $\mathrm{Ng}$ (SoftMax Pro v. 4.0).

\section{Statistical analysis}

In the first study cohort containing individuals with SAD and controls, we analyzed differences in total full-length $\mathrm{Ng}$, meaning the sum of all $\mathrm{Ng} 1-78$ with various modifications and the peptide-to-total full-length $\mathrm{Ng}$ ratio of all $\mathrm{Ng}$ peptides identified by HI-MS. The data in the second study cohort, containing individuals with $\mathrm{SAD}, \mathrm{AAD}, \mathrm{CU}-\mathrm{AP}$, and controls, were analyzed in the same way as for the first study. Because there were more than two groups in this cohort, we first performed the non-parametric Kruskal-Wallis test for differences between groups, followed by post hoc pairwise Mann-Whitney $U$ tests for individual group differences if the Kruskal-Wallis test was significant. All Ng measures in this study were first adjusted for post-mortem delay and age. Additionally, we analyzed the association between $\mathrm{Ng}$ and $\mathrm{A} \beta$ and tau pathology in the second cohort by calculating the Spearman correlation between HI-MS/WB/ ELISA values and both Braak and Thal staging. We tested for group differences in $\mathrm{Ng}$ values between Braak stages $0-\mathrm{I}, \mathrm{II}-\mathrm{IV}, \mathrm{V}-\mathrm{VI}$, and separately between Thal scores $0-1$, $2-3,4-5$, and again separately between CERAD scores 0 , A, B, C-each using the Kruskal-Wallis test with post hoc pairwise Mann-Whitney $U$ tests if the main effect was significance. All tests were two-sided with a significance level set to $p<0.05$. $p$ values for each family of comparisons were adjusted for multiple comparisons using Holm's method to control the family-wise error rate. Statistical analysis was performed using GraphPad Prism 7 (GraphPad Software, La Jolla, USA) and the R programming language (v. 3.4.3).

\section{Results}

\section{Neurogranin is present as both endogenous peptides and modified full-length form}

Brain Ng was characterized using HI-MS and we found that $\mathrm{Ng}$ is present as a variety of short endogenous peptides, all located in the C-terminal part of the protein. In total, 15 peptides were repeatedly detected using MALDI TOF/TOF (Fig. 1) and an additional 24 peptides were identified by highresolution mass spectrometry (Fig. 2 and Online Resource 3). By using a combination of HI-MS and high-resolution MS/MS we found that several post-translational modifications (PTMs) were present on full-length $\mathrm{Ng}$. We were able to identify $\mathrm{Ng} 1-78$ with acetylation and a disulfide bridge, $\mathrm{Ng} 1-78$ with acetylation, disulfide bridge and cysteinyl, and $\mathrm{Ng} 1-78$ with acetylation, disulfide bridge and a glutathione (GSH) (Fig. 3a, c). In addition, all variants could also include one or two oxidations. A detailed data analysis showed that the disulfide bridge was located either between cysteine (C) 3 and $\mathrm{C} 4$ or between $\mathrm{C} 4$ and $\mathrm{C} 9$. GSH and cysteinyl may then be attached on either $\mathrm{C} 9$ or $\mathrm{C} 3$ depending on the location of the disulfide bridge. The acetylation was always attached to the protein N-terminal methionine M1 (Fig. 3b and Online Resource 4) and the oxidations to M1 or M41. Full-length $\mathrm{Ng}$ with the different sets of PTMs also had different retention time profiles (Fig. 3c). When reducing Ng with DTT the peaks representing Ng1-78 containing GSH or cysteinyl were greatly reduced (Fig. 3d, e). These results were confirmed with LC-MS/MS.

\section{The peptide-to-full-length neurogranin ratios are decreased in superior parietal gyrus of sporadic Alzheimer's disease}

In study 1, full-length $\mathrm{Ng}$ as well as 14 endogenous peptides, which were detected in all samples, was quantified in the superior parietal gyrus of individuals with SAD and healthy age-matched controls. After analyzing the ratio between each of the peptides and the sum of $\mathrm{Ng} 1-78$ with the three sets of PTMs, hereby referred to as total full-length $\mathrm{Ng}$, we found that 8 peptide-to-total full-length $\mathrm{Ng}$ ratios were significantly increased in $\mathrm{sAD}$ compared to controls ( $p<0.05$ for all ratios) (Fig. 4 and Online Resource 5), thus indicating increased concentrations of these peptides compared to total full-length $\mathrm{Ng}$. 


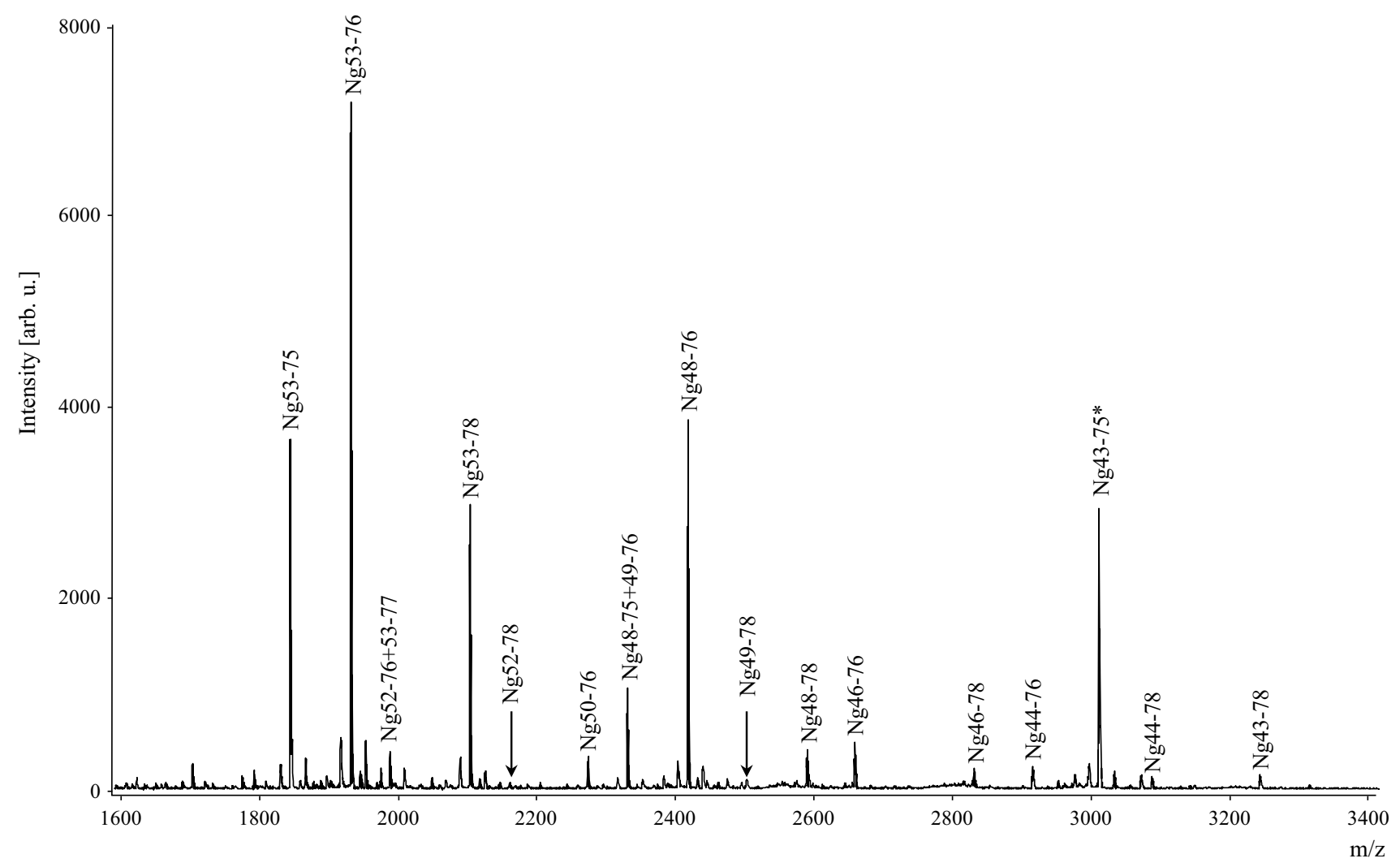

Fig. 1 Hybrid immunoaffinity-mass spectrometric characterization of endogenous neurogranin peptides in human brain tissue. Several short endogenous C-terminal peptides were repeatedly detected in

\section{Neurogranin peptides are increased and full-length neurogranin is decreased in sporadic and familial Alzheimer's disease}

To validate these findings, we first used HI-MS in a second study with temporal cortex from individuals with SAD, fAD, CU-AP and controls. In total ten endogenous peptides, of which all except one were the same as in study 1 , were quantified in a majority of the samples in addition to fulllength $\mathrm{Ng}$. There were significant differences across groups in peptide-to-total full-length $\mathrm{Ng}$ ratios for nine of the ten peptides detected in this study. One of the strongest differences was found in peptide-to-total full-length $\mathrm{Ng}$ ratio of $\mathrm{Ng} 53-78(p=0.0008)$. For this peptide (Fig. 5a), a post hoc test revealed that peptide-to-total full-length $\mathrm{Ng}$ ratio was significantly reduced in $\mathrm{SAD}$ and $\mathrm{fAD}$ compared to controls $(p=0.004$ for $\mathrm{sAD} ; p=0.0005$ for $\mathrm{fAD})$, and compared to CU-AP ( $p=0.007$ for sAD; $p=0.002$ for fAD). Results for the other peptides are summarized in Online Resource 6 and 7.

Furthermore, there was a significant difference in total full-length $\mathrm{Ng}$ concentrations measured by $\mathrm{HI}-\mathrm{MS}$ across groups $(p=0.0008)$. Post hoc analysis showed that total human parietal cortex using the monoclonal antibodies $\mathrm{Ng} 2+\mathrm{Ng} 3$ and MALDI TOF/TOF. Ng43-75* represents internal standard fully labeled with ${ }^{13} \mathrm{C}$

full-length $\mathrm{Ng}$ levels were significantly reduced in individuals with fAD compared to $\mathrm{SAD}(p=0.03)$, CU-AP $(p=0.0003)$, and controls $(p=0.01)$ (Fig. 5b). There was also a trend, although not statistically significant, towards reduced total full-length $\mathrm{Ng}$ in $\mathrm{SAD}$ compared to controls and CU-AP.

In addition to HI-MS, the second cohort was also analyzed by WB (Fig. 5c) and ELISA. To ensure that the monoclonal antibody $\mathrm{Ng} 36$, which was used both in the ELISA and $\mathrm{WB}$, was specific for $\mathrm{Ng}$ it was first characterized by HI-MS. Human brain tissue was analyzed by HI-MS and we were able to confirm that $\mathrm{Ng} 36$ is specific for $\mathrm{Ng}$ and detects the same peptides and full-length $\mathrm{Ng}$ as $\mathrm{Ng} 2$ and Ng3 (Online Resource 8).

For WB, there were significant differences across groups $(p=0.003)$, with again significantly lower concentrations in fAD compared to CU-AP $(p=0.008)$, and controls $(p=0.0002)$ (Fig. 5d). ELISA analysis also showed significant differences across groups $(p=0.008)$, with significantly lower concentrations in fAD compared to CU-AP $(p=0.035)$, and controls $(p=0.003)$, and significantly lower concentrations in SAD compared to CU-AP $(p=0.017)$ (Fig. 5e). 
$\underset{1}{\text { MDCCTENACSKPDDDILDI }}$ PLDDPGANAAAAKIQASFRGHMARKKIKSGERGRKGPGPGGPGGAGVARGGAGGGPSGD $_{30}$

10-SKPDDDILDI PLDDPGANAAAAKIQASFRGHMARKKIKSGERGRKGPGPGGPGGAGVARGGAGGGPSGD-78 10-SKPDDDILDI PLDDPGANAAAAKIQASFRGHMARKKIKSGERGRKGPGPGGPGGAGVARGGAGGGPS-76 22-DDPGANAAAAKIQASFRGHMARKKIKSGERGRKGPGPGGPGGAGVARGGAGGGPSGD-78 31 - AKIQASFRGHMARKKIKSGERGRKGPGPGGPGGAGVARGGAGGGPSGD-78 36-SFRGHMARKKIKSGERGRKGPGPGGPGGAGVARGGAGGGPSGD-78 38-RGHMARKKIKSGERGRKGPGPGGPGGAGVARGGAGGGPSGD-78 41-MARKKIKSGERGRKGPGPGGPGGAGVARGGAGGGPSGD-78 42-ARKKIKSGERGRKGPGPGGPGGAGVARGGAGGGPSGD-78 42-ARKKIKSGERGRKGPGPGGPGGAGVARGGAGGGPS-76 43-RKKIKSGERGRKGPGPGGPGGAGVARGGAGGGPSGD-78 43-RKKIKSGERGRKGPGPGGPGGAGVARGGAGGGPS-76

44-KKIKSGERGRKGPGPGGPGGAGVARGGAGGGPSGD-78

44-KKIKSGERGRKGPGPGGPGGAGVARGGAGGGPS-76

45- KIKSGERGRKGPGPGGPGGAGVARGGAGGGPSGD-78

46-IKSGERGRKGPGPGGPGGAGVARGGAGGGPSGD-78

46-IKSGERGRKGPGPGGPGGAGVARGGAGGGPSG-77

46-IKSGERGRKGPGPGGPGGAGVARGGAGGGPS-76

46 - IKSGERGRKGPGPGGPGGAGVARGGAGGGP-75

48-SGERGRKGPGPGGPGGAGVARGGAGGGPSGD-78

48-SGERGRKGPGPGGPGGAGVARGGAGGGPSG-77

48 - SGERGRKGPGPGGPGGAGVARGGAGGGPS-76

48-SGERGRKGPGPGGPGGAGVARGGAGGGP-75

49-GERGRKGPGPGGPGGAGVARGGAGGGPSGD-78

49-GERGRKGPGPGGPGGAGVARGGAGGGPS-76

49-GERGRKGPGPGGPGGAGVARGGAGGGP-75

50- ERGRKGPGPGGPGGAGVARGGAGGGPSGD-78

50- ERGRKGPGPGGPGGAGVARGGAGGGPS-76

50- ERGRKGPGPGGPGGAGVARGGAGGGP-75

52-GRKGPGPGGPGGAGVARGGAGGGPSGD-78

52-GRKGPGPGGPGGAGVARGGAGGGPS-76

52- GRKGPGPGGPGGAGVARGGAGGGP-75

53- RKGPGPGGPGGAGVARGGAGGGPSGD-78

53- RKGPGPGGPGGAGVARGGAGGGPSG-77

53-RKGPGPGGPGGAGVARGGAGGGPS-76

53-RKGPGPGGPGGAGVARGGAGGGP-75

54 - KGPGPGGPGGAGVARGGAGGGPSGD- 78

54- KGPGPGGPGGAGVARGGAGGGPSG-77

54 - KGPGPGGPGGAGVARGGAGGGPS-76

54- KGPGPGGPGGAGVARGGAGGGP- 75

Fig. 2 Summary of all identified neurogranin peptides in human brain tissue. In total, 39 endogenous $\mathrm{Ng}$ peptides were identified using a combination of HI-MS and high-resolution mass spectrometry

\section{Neurogranin levels differ between degrees of neuropathological changes}

After grouping all individuals from study 2, independent of diagnosis, by Braak stages 0-I (no or little tau pathology), II-IV (moderate tau pathology), and V-VI (high-level tau pathology), we found a significant group difference in total full-length $\mathrm{Ng}, \mathrm{Ng}$ measured by $\mathrm{WB}, \mathrm{Ng}$ measured by ELISA, and peptide-to-total full-length $\mathrm{Ng}$ ratios of all peptides (all $p<0.02$ ). Post hoc tests revealed that Ng levels increased with increasing Braak pathology for each of the tested measurements, results are summarized in Online Resource 9. After grouping individuals independent of diagnosis by Thal stages $0-1,2-3$, and $4-5$, we found a significance group difference only in the peptide-to-total full-length $\mathrm{Ng}$ ratio of $\mathrm{Ng53-78}(p=0.03)$. A post hoc test showed that $\mathrm{Ng}$ values in Thal stages $0-1$ were significantly lower than in stages $2-3(p=0.003)$ and nearly significantly lower than in stages $4-5(p=0.052)$. Results are summarized in Online Resource 9. Finally, after grouping individuals independent of diagnosis by CERAD score $0, \mathrm{~A}, \mathrm{~B}$, and $\mathrm{C}$, we found a significant group difference in total fulllength $\mathrm{Ng}, \mathrm{Ng}$ measured by $\mathrm{WB}, \mathrm{Ng}$ measured by ELISA, and peptide-to-total full-length $\mathrm{Ng}$ ratios of all peptides (all $p<0.03$ ). Again, post hoc tests showed increasing peptideto-total full-length $\mathrm{Ng}$ ratios with increasing CERAD scoring. Results are summarized in Online Resource 9. 


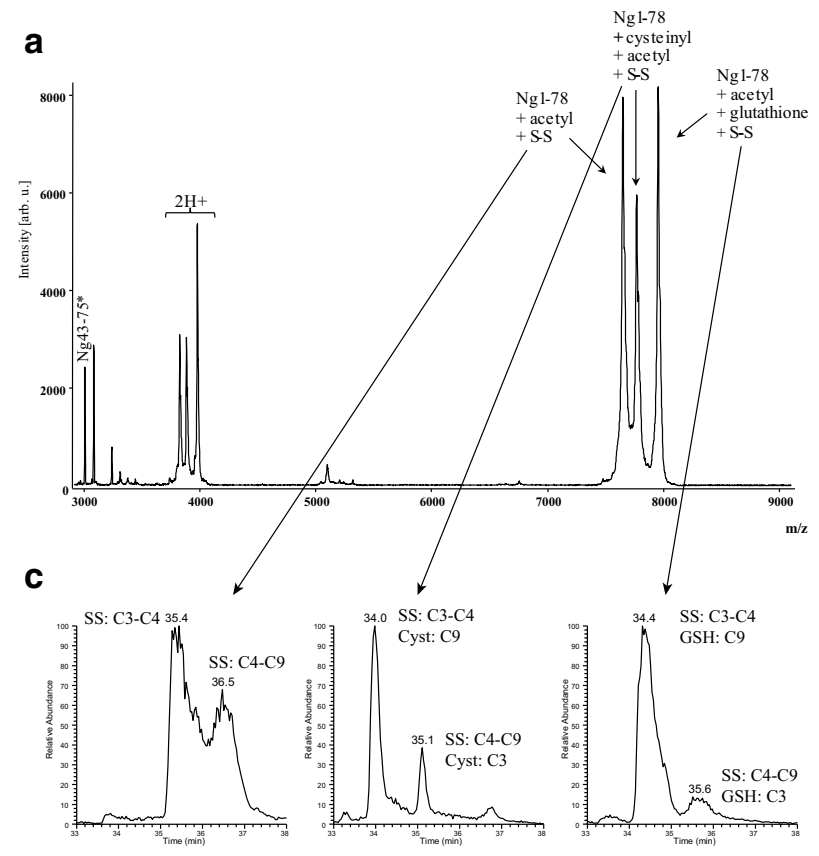

Fig. 3 Hybrid immunoaffinity-mass spectrometric characterization of full-length neurogranin in human brain tissue. A cluster of peaks representing full-length $\mathrm{Ng}$ with different sets PTMs (a). Amino acid sequence of $\mathrm{Ng} 1-78$ with acetyl, disulfide bridge and GSH with the positions of PTMs and $b$ - and $y$-ions identified from a single MS/MS acquisition indicated (b). Full-length $\mathrm{Ng}$ with different PTM arrangements had different retention time during high-resolution LC-MS/MS analysis (c). Expansion of the $\mathrm{m} / \mathrm{z}$ range around b
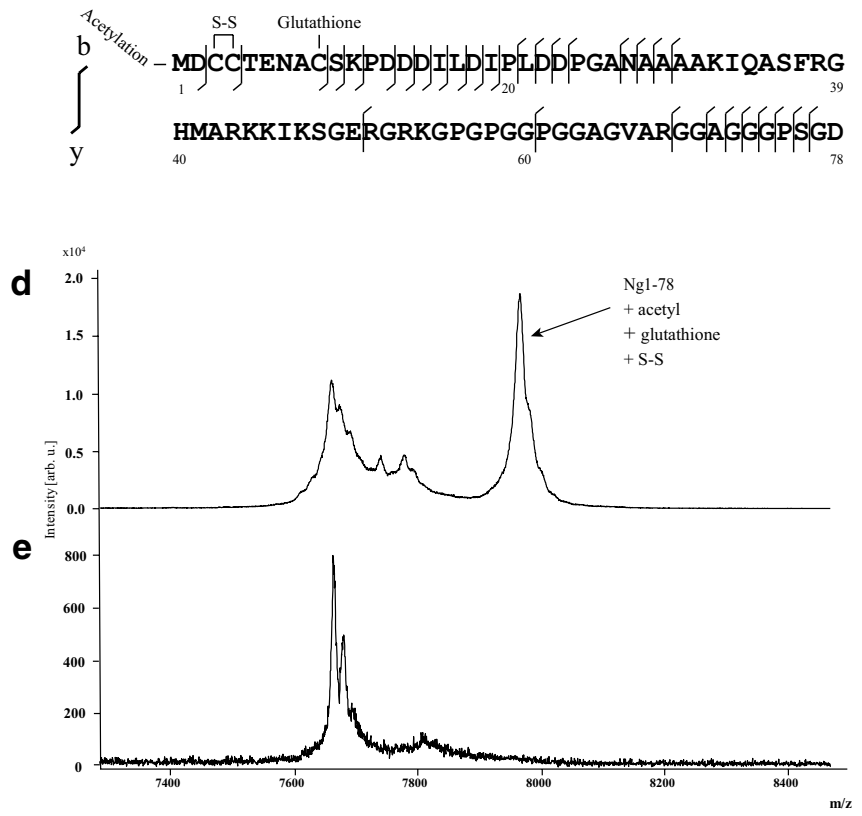

$\mathrm{m} / \mathrm{z} 7500$ in a MALDI mass spectrum from human brain tissue after heat-treatment without reduction with DTT showed a cluster of peaks representing $\mathrm{Ng} 1-78$. The rightmost peak represents $\mathrm{Ng} 1-$ $78+$ acetyl $+\mathrm{GSH}+$ disulfide bridge (d). A similar mass spectrum from human brain tissue after heat-treatment and reduction with DTT showed another cluster of peaks representing full-length $\mathrm{Ng}$. Here the peak representing $\mathrm{Ng} 1-78+$ acetyl $+\mathrm{GSH}+$ disulfide bridge was greatly reduced $(\mathbf{e})$
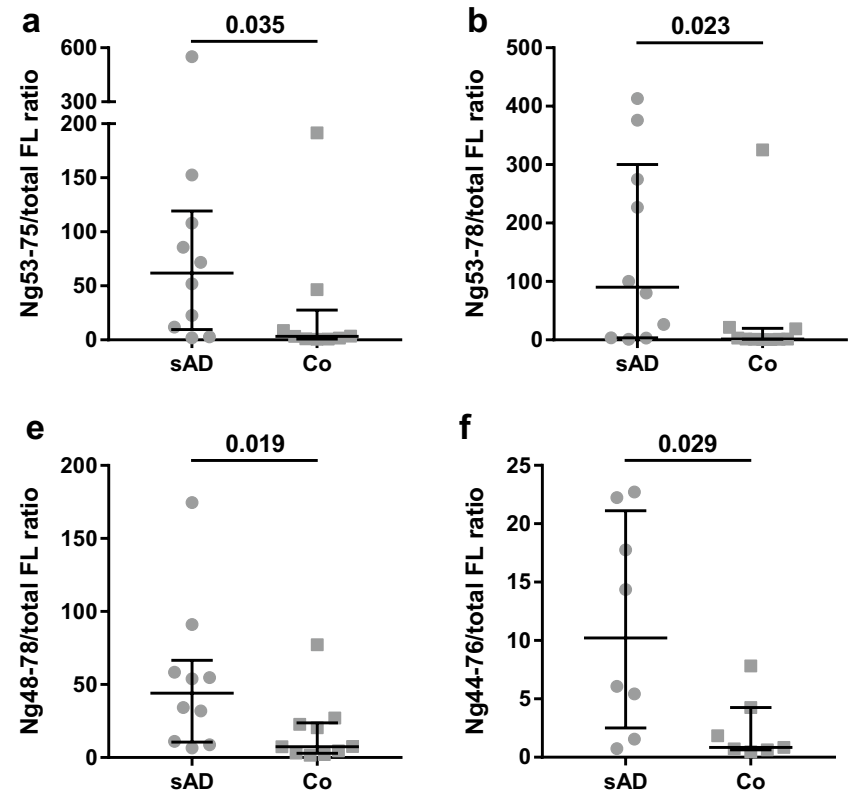

Fig. 4 Scatterplots displaying the result from hybrid-immunoaffinity mass spectrometry in study 1 . Scatterplots displaying the peptideto-total full-length $\mathrm{Ng}$ ratio $\times 1000$ for $\mathrm{Ng} 53-75$ (a), $\mathrm{Ng} 53-78$ (b), Ng51-78 (c), Ng48-76 (d), Ng48-78 (e), Ng44-76 (f), Ng42-78 (g)
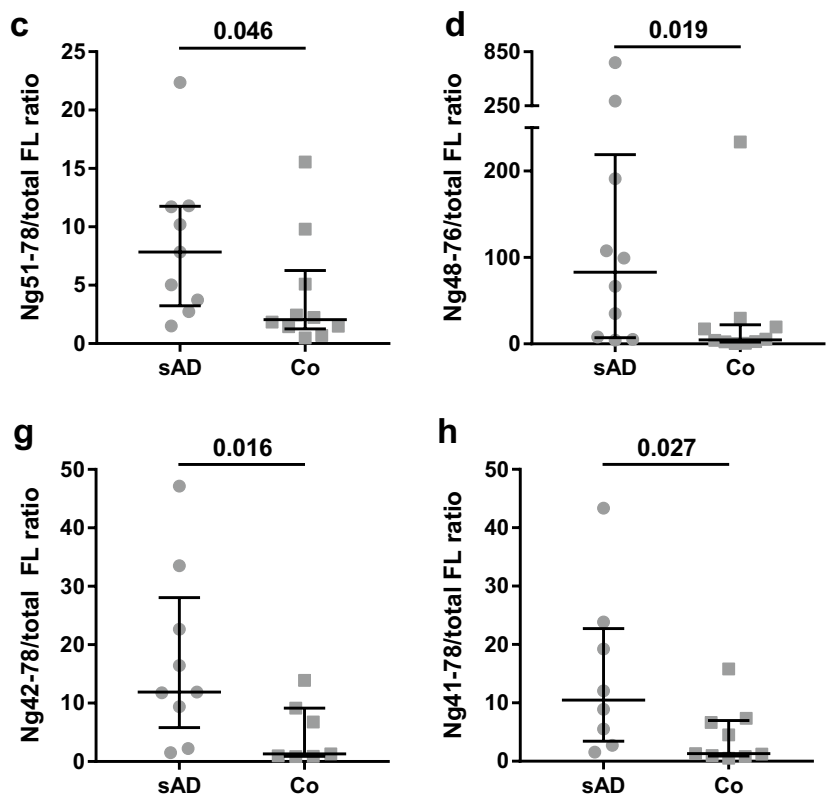

and $\mathrm{Ng} 41-78$ (h). The data presented are median and interquartile ranges. Differences between groups were assessed using Mann-Whitney $U$ test 
Fig. 5 Scatterplots and western blot analysis of study 2 . Scatterplot displaying the peptideto-total full-length $\mathrm{Ng}$ ratio $\times 1000$ for Ng53-78. " Sample ratio is $>150,000$ (a). Scatterplot displaying total full-length $\mathrm{Ng}$ concentration measured by HI-MS (b). WB using the monoclonal antibody $\mathrm{Ng} 36$ (left blot) or no primary antibody (right blot). Briefly, samples were relatively quantified in WB by including a standard curve of recombinant Ng-MYC-DDK protein on each gel. Lanes 1-5: standard curve of $\mathrm{Ng}-\mathrm{Myc}-$ DKK fusion protein ranging from 25 to $1.56 \mathrm{ng}$. Lane 6 : quality control (QC) brain tissue sample. Lanes 7-9: patient samples from study 2. Lane 10: QC tissue sample. Lane 11: $\mathrm{Ng}-\mathrm{Myc}-\mathrm{DKK}$ fusion protein $12.5 \mathrm{ng}$. Lanes 10 and 11 were used as negative controls (c). Scatterplot displaying results from WB analysis. The $y$-axis displays the $\mathrm{Ng}$ concentration in $\mathrm{ng} / \mathrm{mg}$ total protein in each sample (d). Scatterplot displaying ELISA results. The $y$-axis displays the $\mathrm{Ng}$ concentration in $\mathrm{ng} / \mathrm{mg}$ total protein in each sample (e). The data presented are median and interquartile ranges. Comparisons between groups were performed using KruskalWallis test with data adjusted for post-mortem delay, followed by pairwise Mann-Whitney $U$ tests if significant

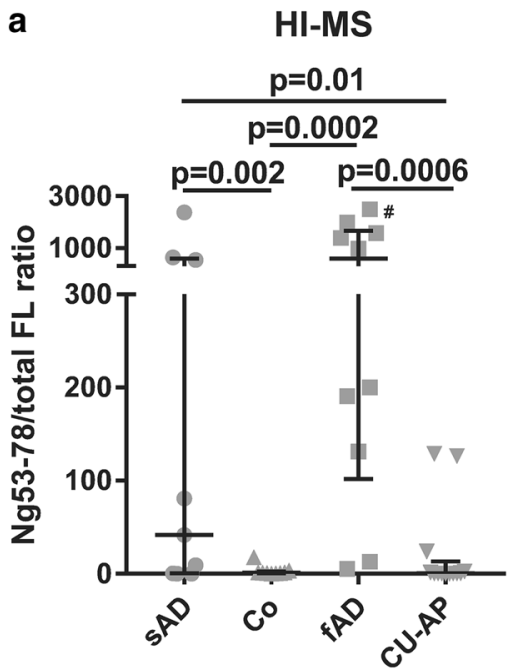

b

HI-MS
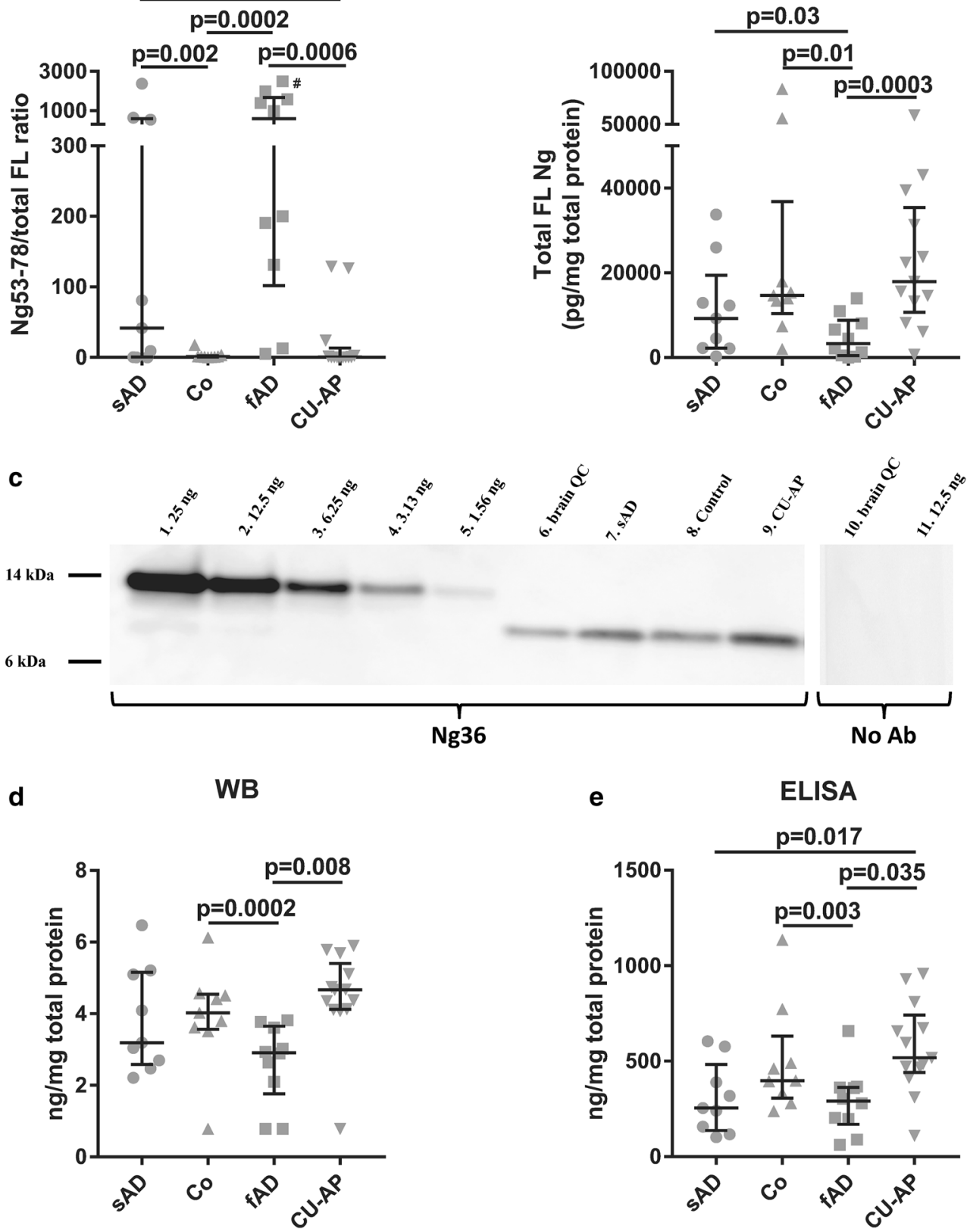

\section{Discussion}

In 2015 we used HI-MS to show that several endogenous $\mathrm{Ng}$ peptides are present in both CSF and brain tissue and $\mathrm{Ng} 48-76$ was increased in sAD CSF [32] Therefore we aimed to investigate $\mathrm{Ng}$ in brain tissue in more detail by combining HI-MS, ELISA and WB analysis to find an explanation to why $\mathrm{Ng}$ seems to be decreased in SAD brains, as shown previously $[15,49]$, and increased in CSF from sAD patients. In the current study, we have performed an extensive characterization of $\mathrm{Ng}$ in post-mortem human brain tissue and quantified and compared the expression pattern of brain $\mathrm{Ng}$ in relation to $\mathrm{AD}$ pathology in $\mathrm{SAD}, \mathrm{fAD}$, and CU-AP to controls.

HI-MS combined with high-resolution MS/MS showed that full-length $\mathrm{Ng}$ is post-translationally modified by the addition of an $\mathrm{N}$-terminal acetyl group, disulfide bridge (at C3-C4 or C4-C9), cysteinyl (at C3 or C9), and GSH (at C3 or C9), but does not exclude the possibility of other combinations of the reported variants, or different PTMs being present on full-length or nearly full-length $\mathrm{Ng}$. Support of the reported PTMs include MS/MS data of the individual 
protein species and that the protein containing the different PTM combinations had different retention times. It has previously been shown that reducing samples with DTT prevents GSH adducts from forming [2]. The fact that the peak representing $\mathrm{Ng} 1-78$ with disulfide bridge and GSH was greatly diminished when reducing the sample with DTT add additional proof that $\mathrm{GSH}$ is present on $\mathrm{Ng}$ at a cysteine. Our results show that a substantial portion of full-length $\mathrm{Ng}$ has GSH as a PTM. GSH, which is the most abundant antioxidant in the brain, plays a significant role in counteracting oxidative stress by reacting with free radicals [43]. Proteins that are sensitive to redox might be protected from OS by glutathionylation and several proteins in AD brain, including p53 which can initiate apoptosis, have been identified as having a GSH PTM [19]. Loss of synapses is considered the mechanism that precedes neuronal loss and correlates best with cognitive impairment in $\mathrm{AD}[18,51,54,57]$. Both in vivo and in vitro studies suggest a direct relationship between synaptic dysfunction and oxidative stress in AD $[14,29,35,48]$, thus indicating that a GSH PTM on intact $\mathrm{Ng}$ might be a means of protection against oxidative stress to preserve protein function.

We were able to quantify several $\mathrm{Ng}$ peptides in both studies, although some of them differed between the two materials. This was most likely because the tissues used in the studies were from different regions. Using HI-MS we were able to quantify several peptides as well as full-length $\mathrm{Ng}$ with PTMs separately. In WB, the peptides were probably too small and exited the gel meaning that this method mainly quantifies full-length, or nearly full-length, $\mathrm{Ng}$. In contrast, the ELISA most likely detects a mixture of both full-length $\mathrm{Ng}$ and many different peptides.

AD pathology (plaques and tangles) are common in older non-demented individuals, with an estimated $30-40 \%$ of cognitively intact elderly classed as positive upon autopsy [7, 31, 47]. Recently, new guidelines for diagnosis of AD based on biomarkers reflecting the key pathologies were published by the NIA and the AA to update and unify the 2011 NIA/AA guidelines according to the current understanding of the disease [40]. In the new 2018 NIA/AA guidelines for researchers, a diagnosis of $\mathrm{AD}$ is defined by its underlying pathologic processes that can be documented by post-mortem examination or followed in vivo using imaging or fluid biomarkers and not by symptoms or signs, such as cognitive decline, which are rather clinical consequences of the resulting neurodegeneration [27]. According to these criteria, the CU-AP would be classified as preclinical Alzheimer's pathologic change in the Alzheimer's continuum. In the present study, the SAD and CU-AP groups were different from each other with SAD having significantly higher concentrations for many of the measured $\mathrm{Ng}$ peptides compared to full-length $\mathrm{Ng}$ than CU-AP. In addition, the sAD and fAD subjects appear to be subjected to a similar processing of full-length $\mathrm{Ng}$ into peptides, whereas for controls and CU-AP the degradation is not so evident. Most importantly, the CU-AP individuals do not have any signs of lowered cognitive function despite mild to moderate neuropathological changes. Thus, grouping the $\mathrm{AD}$ and $\mathrm{CU}-\mathrm{AP}$ subjects together would not be appropriate since CU-AP do not demonstrate an increase of $\mathrm{Ng}$ peptides and a decrease of full-length $\mathrm{Ng}$, which might reflect degenerating synapses. In addition, differences between CU-AP and SAD have been described previously. Post-mortem brain tissue from half of the CU-AP individuals included in study 2 were previously analyzed and shown to contain less N-terminally truncated and pyroglutamate-modified $\mathrm{A} \beta$ peptides compared to $\mathrm{SAD}$ cases [44]. This would suggest that these individuals indeed are different from patients with $\mathrm{SAD}$, and most likely also fAD, even though they share neuropathological changes in the brain.

Even though most CU-AP individuals have tau and amyloid pathology above what can be expected for their age they somehow still managed to remain cognitively intact. There is a possibility that these subjects were able to compensate for the synaptic damage and loss induced by these pathologies, thus keeping their full-length $\mathrm{Ng}$ levels in the same range as controls. Mouse models have shown that upregulation of $\mathrm{Ng}$ not only improves LTP but also enhances cognitive performance [65], hence suggesting that an increase in $\mathrm{Ng}$ might be beneficial for cognition in humans as well. As there was a trend towards increased full-length $\mathrm{Ng}$ in CU-AP compared to controls as measured by $\mathrm{WB}$, it is possible that the CU-AP individuals are able to respond to the pathological changes and counteract or compensate for the cognitive decline these would otherwise cause, perhaps by increasing the numbers of synapses or simply producing more full-length $\mathrm{Ng}$ thus providing them with the means of a cognitive reserve.

As peptide-to-total full-length $\mathrm{Ng}$ ratios were increased in SAD compared to controls in both studies, and in the second study also for sAD compared to CU-AP and in FAD compared to both controls and CU-AP, there seems to be a shift from intact protein to endogenous peptides in both forms of AD. WB mainly detects full-length, or nearly fulllength, $\mathrm{Ng}$ since the peptides appears to be too small and most likely exit the gel. Consequently, WB results also support the hypothesis of decreased full-length $\mathrm{Ng}$ as fAD had significantly lower concentrations compared to CU-AP as well as a trend towards lower levels compared to SAD. Similarly, the SAD group also had an apparent trend of lower concentrations compared to both controls and CU-AP in both WB and ELISA. In contrast to WB, the ELISA most likely detects a mixture of both full-length $\mathrm{Ng}$ and many different peptides as both $\mathrm{Ng} 2$ and $\mathrm{Ng} 36$ are able to bind $\mathrm{Ng}$ in the form of both peptides and full-length protein. This might in turn explain why the group separation was less evident compared to WB. However, HI-MS analysis showed that 
even though peptide concentrations are increased in both SAD and fAD there is still very high levels of full-length $\mathrm{Ng}$ left, which is most likely why the ELISA results still are more similar to WB than HI-MS. Taken together, this shows that full-length $\mathrm{Ng}$ most likely is degraded into at least some of the peptides measured by HI-MS. The results from the ELISA are very similar to WB with significantly lower concentrations in fAD compared to CU-AP and, although not reaching statistical significance, a trend towards lower concentrations in $\mathrm{AD}$ compared to both controls and CU-AP and as well as when comparing fAD with controls. Thus, the three methods indicate the same conclusion; that full-length $\mathrm{Ng}$ is decreased in both $\mathrm{SAD}$ and fAD.

Since we saw clear differences in the peptide-to-total fulllength $\mathrm{Ng}$ ratios between the two $\mathrm{AD}$ groups compared to controls and CU-AP for many of the detected peptides, it might be of potential interest to develop an assay capable of measuring these two pools of $\mathrm{Ng}$ in the future. Currently, full-length and peptide $\mathrm{Ng}$ are measured by HI-MS, which is both quite time-consuming and inefficient compared to an immunoassay. The ELISA presented here most likely quantifies both full-length and peptide $\mathrm{Ng}$, and the separation between the groups is not as good compared to peptide-tototal full-length $\mathrm{Ng}$ ratio. In theory, it might be possible to develop two assays that quantify peptide and full-length $\mathrm{Ng}$, respectively. Using a similar approach, the $A \beta 42 / 40$ ratio has successfully been shown to increase diagnostic accuracy $[22,34,56]$ and have diagnostic value in clinical settings [21], as well as circumventing the issue of high- and lowproducers [62].

It is well established that neuronal and synaptic loss are early and central events in AD pathology [18, 37, 52] and that synaptic density is reduced by more than $30 \%$ even in the earliest stages of AD [16]. In fact, both cognitive decline and disease progression can be monitored by measuring synaptic loss as it appears to be more closely correlated with cognitive deficits than plaque and tangle load $[37,52,58]$. In rodents, $\mathrm{Ng}$ mRNA and protein concentrations in the hippocampus decrease with age and are related to CNS dysfunction [41] and knockdown models display both impaired cognition and reduced LTP [23]. In humans, it has been shown that high CSF Ng was positively associated with increased rate of hippocampal atrophy [46] as well as other parts of the brain [59]. Taken together, it seems probable that the proteolytic processing of full-length $\mathrm{Ng}$ into peptides during neurodegeneration, visualized here as increased peptide-to-total full-length $\mathrm{Ng}$ concentrations in $\mathrm{SAD}$ and $\mathrm{AAD}$, may be triggered by synaptic degeneration and neuronal loss. According to the literature, at present day $\mathrm{Ng}$ does not seem to be a confirmed substrate for any enzymes. However, recently we showed that that calpain-1 and prolyl endopeptidase are capable of cleaving full-length $\mathrm{Ng}$ within the IQ domain and near the C-terminal end, respectively in vitro resulting in several of the endogenous peptides we have found in brain tissue and CSF [5]. Notably, several of the endogenous peptides identified from brain tissue start just after the C-terminal end of the IQ motif. Since the IQ motif is needed for calmodulin-binding [3,50], the cleavage would most likely inhibit $\mathrm{Ng}$ binding to calmodulin, as it does for GAP-43 [64], which in turn would affect LTP and therefore formation of long-term memory excitation $[4,20,25,63]$. Future studies on the role of this enzymatic activity would be of interest to further understand the link between neurodegeneration and enzymatic cleavage of $\mathrm{Ng}$ into the observed peptides as they are not all accounted for by cleavage of calpain- 1 and prolyl endopeptidase alone.

We previously showed a strong association between CSF $\mathrm{Ng}$ and degree of AD neuropathology independent of diagnosis in a study containing several neurodegenerative diseases [45]. In the present study, we confirmed the CSF study as brain $\mathrm{Ng}$ levels were increasing with both Braak stage, CERAD score and to some extent Thal phase, meaning that $\mathrm{Ng}$ is associated with both $\mathrm{A} \beta$ and tau pathology. However, CERAD scores showed a much stronger association with $\mathrm{Ng}$ levels compared to Thal phases. This may be due to the fact that Thal phases are a measure of how far the $A \beta$ pathology has spread around the brain, regardless of how much $A \beta$ is present, whereas the CERAD score is a measure of the quantity of $A \beta$ plaques found in the cortical areas. For example, to reach a Thal phase $1, A \beta$ plaques must be present in any cortical region, but this gives no information at all about the actual number of plaques present. In conclusion, our data shows that $\mathrm{Ng}$ is much more closely associated with plaque load compared to the spreading of $A \beta$ pathology. This is in line with previous findings that $\mathrm{CSF} \mathrm{Ng}$ is positively correlated with CERAD scores in autopsy-confirmed cases of AD [45]. Evaluating the levels of Ng in CSF from patients with primary tauopathies, without amyloid plaque pathology, might give us further insight into the association with tau as previous studies on CSF Ng have shown strong correlations with CSF tau [17, 24, 30, 33, 38, 61].

The major limitations of this paper are the small sample sizes in both studies and significant age differences between the groups in study 2 . The sample sizes are limited since high-quality post-mortem tissue meeting the neuropathological demands of the groups included in these studies is very restricted. Regarding age differences in study 2 , fAD was significantly younger than both controls and CU-AP, and SAD was younger than CU-AP. However, as SAD and controls were age-matched in both studies, and there was no significant difference in age between controls and CU-AP, it is unlikely that the reported differences in $\mathrm{Ng}$ concentrations are due to the age differences. Since this study was performed on post-mortem tissue, it was difficult to ensure age matching between $\mathrm{AD}$ and control groups of the two 
separate studies as well as all four groups included in the second study, especially considering the fAD group will be younger than the $\mathrm{SAD}$ group. To compensate for any impact the age differences may have on the results, all data was adjusted for age. Post-mortem delay was significantly shorter in $\mathrm{AAD}$ compared to $\mathrm{CU}-\mathrm{AP}$ therefore statistical analysis were adjusted for this.

We have performed an extensive characterization of the postsynaptic protein $\mathrm{Ng}$ in human brain tissue. Using HI-MS it was shown that $\mathrm{Ng}$ is present as a variety of endogenous peptides as well as post-translationally modified full-length protein. The identified PTMs were acetyl, disulfide bridge, cysteinyl, and GSH modifications, as well as oxidation. The most important discovery was that $\mathrm{SAD}$ and $\mathrm{fAD}$ had increased concentrations of endogenous peptides as well as a decrease in full-length $\mathrm{Ng}$ indicating a shift from intact protein towards peptides. This shift was not present in healthy controls or CU-AP individuals, of which the latter have both plaque and tangle pathology but no cognitive impairment, hence indicating that $\mathrm{Ng}$ is a biomarker for AD-related synaptic degeneration that leads to cognitive decline. This was also supported by the finding that $\mathrm{Ng} \mathrm{lev-}$ els were strongly associated with degree of neuropathological changes, as measured by Braak stage, Thal phases, and CERAD scores, independent of diagnosis.

Funding The study was supported by grants from the Swedish and European Research Councils, the Torsten Söderberg Foundation, the Swedish Brain Foundation, the Knut and Alice Wallenberg Foundation, Frimurarestiftelsen, Stiftelsen för Gamla Tjänarinnor, Foundation for Research on Alzheimer, the Swedish Alzheimer Foundation, and Swedish State Support for Clinical Research (ALFGBG). TL is supported by an Alzheimer's Research UK senior fellowship and the Leonard Wolfson Centre for Experimental Neurology. HZ and CM are supported by the UK Dementia Research Institute at UCL. The Queen Square Brain Bank is supported by the Reta Lila Weston Institute for Neurological Studies and the Medical Research Council.

\section{Compliance with ethical standards}

Conflict of interest HZ is a co-founder of Brain Biomarker Solutions in Gothenburg AB, a GU Ventures-based platform company at the University of Gothenburg, has served at advisory boards of Eli Lilly, Roche Diagnostics and Wave and has received travel support from TEVA. KB has served as a consultant or at advisory boards for Alzheon, BioArctic, Biogen, Eli Lilly, Fujirebio Europe, IBL International, Merck, Pfizer, and Roche Diagnostics, and is a co-founder of Brain Biomarker Solutions in Gothenburg AB, a GU Ventures-based platform company at the University of Gothenburg. KH has served as consultant for Eisai and Abbvie.

Open Access This article is distributed under the terms of the Creative Commons Attribution 4.0 International License (http://creativeco mmons.org/licenses/by/4.0/), which permits unrestricted use, distribution, and reproduction in any medium, provided you give appropriate credit to the original author(s) and the source, provide a link to the Creative Commons license, and indicate if changes were made.

\section{References}

1. Alzheimer's Association (2016) 2016 Alzheimer's disease facts and figures. Alzheimers Dement 12:459-509

2. Aussedat B, Sagan S, Chassaing G, Bolbach G, Burlina F (2006) Quantification of the efficiency of cargo delivery by peptidic and pseudo-peptidic Trojan carriers using MALDI-TOF mass spectrometry. Biochim Biophys Acta 1758:375-383. https://doi org/10.1016/j.bbamem.2006.01.012

3. Bahler M, Rhoads A (2002) Calmodulin signaling via the IQ motif. FEBS Lett 513:107-113

4. Baudier J, Deloulme JC, Van Dorsselaer A, Black D, Matthes HW (1991) Purification and characterization of a brain-specific protein kinase $\mathrm{C}$ substrate, neurogranin (p17). Identification of a consensus amino acid sequence between neurogranin and neuromodulin (GAP43) that corresponds to the protein kinase $\mathrm{C}$ phosphorylation site and the calmodulin-binding domain. J Biol Chem 266:229-237

5. Becker B, Nazir FH, Brinkmalm G, Camporesi E, Kvartsberg $\mathrm{H}$, Portelius E et al (2018) Alzheimer-associated cerebrospinal fluid fragments of neurogranin are generated by Calpain- 1 and prolyl endopeptidase. Mol Neurodegener 13:47. https://doi. org/10.1186/s13024-018-0279-z

6. Bekris LM, Yu CE, Bird TD, Tsuang DW (2010) Genetics of Alzheimer disease. J Geriatr Psychiatry Neurol 23:213-227. https://doi.org/10.1177/0891988710383571

7. Bennett DA, Schneider JA, Arvanitakis Z, Kelly JF, Aggarwal NT, Shah RC et al (2006) Neuropathology of older persons without cognitive impairment from two community-based studies. Neurology 66:1837-1844. https://doi.org/10.1212/01. wnl.0000219668.47116.e6

8. Blennow K, Bogdanovic N, Alafuzoff I, Ekman R, Davidsson P (1996) Synaptic pathology in Alzheimer's disease: relation to severity of dementia, but not to senile plaques, neurofibrillary tangles, or the ApoE4 allele. J Neural Transm 103:603-618. https://doi.org/10.1007/BF01273157 (Vienna)

9. Blennow K, de Leon MJ, Zetterberg H (2006) Alzheimer's disease. Lancet 368:387-403. https://doi.org/10.1016/S0140 -6736(06)69113-7

10. Bogdanovic N, Davidsson P, Gottfries J, VIW B, Blennow K (2002) Regional and cellular distribution of synaptic proteins in the normal human brain. Brain Aging 2:18-30

11. Braak H, Braak E (1991) Neuropathological stageing of Alzheimer-related changes. Acta Neuropathol 82:239-259

12. Brinkmalm G, Portelius E, Ohrfelt A, Mattsson N, Persson R, Gustavsson MK et al (2012) An online nano-LC-ESI-FTICRMS method for comprehensive characterization of endogenous fragments from amyloid beta and amyloid precursor protein in human and cat cerebrospinal fluid. J Mass Spectrom 47:591603. https://doi.org/10.1002/jms.2987

13. Brouwers N, Sleegers K, Van Broeckhoven C (2008) Molecular genetics of Alzheimer's disease: an update. Ann Med 40:562583. https://doi.org/10.1080/07853890802186905

14. Calkins MJ, Manczak M, Mao P, Shirendeb U, Reddy PH (2011) Impaired mitochondrial biogenesis, defective axonal transport of mitochondria, abnormal mitochondrial dynamics and synaptic degeneration in a mouse model of Alzheimer's disease. Hum Mol Genet 20:4515-4529. https://doi.org/10.1093/hmg/ddr381

15. Davidsson P, Blennow K (1998) Neurochemical dissection of synaptic pathology in Alzheimer's disease. Int Psychogeriatr 10:11-23

16. Davies CA, Mann DM, Sumpter PQ, Yates PO (1987) A quantitative morphometric analysis of the neuronal and synaptic content of the frontal and temporal cortex in patients with Alzheimer's disease. J Neurol Sci 78:151-164 
17. De Vos A, Jacobs D, Struyfs H, Fransen E, Andersson K, Portelius $\mathrm{E}$ et al (2015) C-terminal neurogranin is increased in cerebrospinal fluid but unchanged in plasma in Alzheimer's disease. Alzheimers Dement 11:1461-1469. https://doi.org/10.1016/j. jalz.2015.05.012

18. DeKosky ST, Scheff SW (1990) Synapse loss in frontal cortex biopsies in Alzheimer's disease: correlation with cognitive severity. Ann Neurol 27:457-464. https://doi.org/10.1002/ ana.410270502

19. Di Domenico F, Cenini G, Sultana R, Perluigi M, Uberti D, Memo $M$ et al (2009) Glutathionylation of the pro-apoptotic protein p53 in Alzheimer's disease brain: implications for AD pathogenesis. Neurochem Res 34:727-733. https://doi. org/10.1007/s11064-009-9924-9

20. Diez-Guerra FJ (2010) Neurogranin, a link between calcium/ calmodulin and protein kinase $\mathrm{C}$ signaling in synaptic plasticity. IUBMB Life 62:597-606. https://doi.org/10.1002/iub.357

21. Dumurgier J, Schraen S, Gabelle A, Vercruysse O, Bombois S, Laplanche JL et al (2015) Cerebrospinal fluid amyloid-beta 42/40 ratio in clinical setting of memory centers: a multicentric study. Alzheimers Res Ther 7:30. https://doi.org/10.1186/s1319 5-015-0114-5

22. Hansson O, Zetterberg H, Buchhave P, Andreasson U, Londos E, Minthon L et al (2007) Prediction of Alzheimer's disease using the CSF Abeta42/Abeta40 ratio in patients with mild cognitive impairment. Dement Geriatr Cogn Disord 23:316-320. https:// doi.org/10.1159/000100926

23. Hayashi Y (2009) Long-term potentiation: two pathways meet at neurogranin. EMBO J 28:2859-2860. https://doi.org/10.1038/ emboj.2009.273

24. Hellwig K, Kvartsberg H, Portelius E, Andreasson U, Oberstein TJ, Lewczuk P et al (2015) Neurogranin and YKL-40: independent markers of synaptic degeneration and neuroinflammation in Alzheimer's disease. Alzheimers Res Ther 7:74. https://doi. org/10.1186/s13195-015-0161-y

25. Huang KP, Huang FL, Jager T, Li J, Reymann KG, Balschun D (2004) Neurogranin/RC3 enhances long-term potentiation and learning by promoting calcium-mediated signaling. J Neurosci 24:10660-10669. https://doi.org/10.1523/JNEUR OSCI.2213-04.2004

26. Hyman BT, Phelps CH, Beach TG, Bigio EH, Cairns NJ, Carrillo MC et al (2012) National Institute on Aging-Alzheimer's Association guidelines for the neuropathologic assessment of Alzheimer's disease. Alzheimers Dement 8:1-13. https://doi.org/10.1016/j. jalz.2011.10.007

27. Jack CR Jr, Bennett DA, Blennow K, Carrillo MC, Dunn B, Haeberlein SB et al (2018) NIA-AA Research Framework: toward a biological definition of Alzheimer's disease. Alzheimers Dement 14:535-562. https://doi.org/10.1016/j.jalz.2018.02.018

28. Janelidze S, Hertze J, Zetterberg H, Landqvist Waldo M, Santillo A, Blennow $\mathrm{K}$ et al (2016) Cerebrospinal fluid neurogranin and YKL-40 as biomarkers of Alzheimer's disease. Ann Clin Transl Neurol 3:12-20. https://doi.org/10.1002/acn3.266

29. Kamat PK, Kalani A, Rai S, Swarnkar S, Tota S, Nath C et al (2016) Mechanism of oxidative stress and synapse dysfunction in the pathogenesis of Alzheimer's disease: understanding the therapeutics strategies. Mol Neurobiol 53:648-661. https://doi. org/10.1007/s12035-014-9053-6

30. Kester MI, Teunissen CE, Crimmins DL, Herries EM, Ladenson JH, Scheltens P et al (2015) Neurogranin as a cerebrospinal fluid biomarker for synaptic loss in symptomatic Alzheimer disease. JAMA Neurol 72:1275-1280. https://doi.org/10.1001/jamaneurol .2015.1867

31. Knopman DS, Parisi JE, Salviati A, Floriach-Robert M, Boeve BF, Ivnik RJ et al (2003) Neuropathology of cognitively normal elderly. J Neuropathol Exp Neurol 62:1087-1095
32. Kvartsberg H, Duits FH, Ingelsson M, Andreasen N, Ohrfelt A, Andersson $\mathrm{K}$ et al (2015) Cerebrospinal fluid levels of the synaptic protein neurogranin correlates with cognitive decline in prodromal Alzheimer's disease. Alzheimers Dement 11:1180-1190. https:// doi.org/10.1016/j.jalz.2014.10.009

33. Kvartsberg H, Portelius E, Andreasson U, Brinkmalm G, Hellwig $\mathrm{K}$, Lelental $\mathrm{N}$ et al (2015) Characterization of the postsynaptic protein neurogranin in paired cerebrospinal fluid and plasma samples from Alzheimer's disease patients and healthy controls. Alzheimers Res Ther 7:40. https://doi.org/10.1186/s1319 5-015-0124-3

34. Lewczuk P, Lelental N, Spitzer P, Maler JM, Kornhuber J (2015) Amyloid-beta 42/40 cerebrospinal fluid concentration ratio in the diagnostics of Alzheimer's disease: validation of two novel assays. J Alzheimers Dis 43:183-191. https://doi. org/10.3233/JAD-140771

35. Manczak M, Anekonda TS, Henson E, Park BS, Quinn J, Reddy PH (2006) Mitochondria are a direct site of A beta accumulation in Alzheimer's disease neurons: implications for free radical generation and oxidative damage in disease progression. Hum Mol Genet 15:1437-1449. https://doi.org/10.1093/hmg/dd1066

36. Masliah E, Hansen L, Albright T, Mallory M, Terry RD (1991) Immunoelectron microscopic study of synaptic pathology in Alzheimer's disease. Acta Neuropathol 81:428-433

37. Masliah E, Mallory M, Alford M, DeTeresa R, Hansen LA, McKeel DW et al (2001) Altered expression of synaptic proteins occurs early during progression of Alzheimer's disease. Neurology $56: 127-129$

38. Mattsson N, Insel PS, Palmqvist S, Portelius E, Zetterberg H, Weiner $\mathrm{M}$ et al (2016) Cerebrospinal fluid tau, neurogranin, and neurofilament light in Alzheimer's disease. EMBO Mol Med 8:1184-1196. https://doi.org/10.15252/emmm.201606540

39. McKhann G, Drachman D, Folstein M, Katzman R, Price D, Stadlan EM (1984) Clinical diagnosis of Alzheimer's disease: report of the NINCDS-ADRDA Work Group under the auspices of Department of Health and Human Services Task Force on Alzheimer's disease. Neurology 34:939-944

40. McKhann GM, Knopman DS, Chertkow H, Hyman BT, Jack CR Jr, Kawas CH et al (2011) The diagnosis of dementia due to Alzheimer's disease: recommendations from the National Institute on Aging-Alzheimer's Association workgroups on diagnostic guidelines for Alzheimer's disease. Alzheimers Dement 7:263-269. https://doi.org/10.1016/j.jalz.2011.03.005

41. Mons N, Enderlin V, Jaffard R, Higueret P (2001) Selective agerelated changes in the $\mathrm{PKC}$-sensitive, calmodulin-binding protein, neurogranin, in the mouse brain. J Neurochem 79:859-867

42. Montine TJ, Phelps CH, Beach TG, Bigio EH, Cairns NJ, Dickson DW et al (2012) National Institute on Aging-Alzheimer's Association guidelines for the neuropathologic assessment of Alzheimer's disease: a practical approach. Acta Neuropathol 123:1-11. https://doi.org/10.1007/s00401-011-0910-3

43. Pocernich CB, Butterfield DA (2012) Elevation of glutathione as a therapeutic strategy in Alzheimer disease. Biochim Biophys Acta 1822:625-630. https://doi.org/10.1016/j.bbadi s.2011.10.003

44. Portelius E, Lashley T, Westerlund A, Persson R, Fox NC, Blennow $\mathrm{K}$ et al (2015) Brain amyloid-beta fragment signatures in pathological ageing and Alzheimer's disease by hybrid immunoprecipitation mass spectrometry. Neurodegener Dis 15:50-57. https://doi.org/10.1159/000369465

45. Portelius E, Olsson B, Höglund K, Cullen NC, Kvartsberg H, Andreasson U et al (2018) Cerebrospinal fluid neurogranin concentration in neurodegeneration: relation to clinical phenotypes and neuropathology. Acta Neuropathol. https://doi.org/10.1007/ s00401-018-1851-x 
46. Portelius E, Zetterberg H, Skillback T, Tornqvist U, Andreasson U, Trojanowski JQ et al (2015) Cerebrospinal fluid neurogranin: relation to cognition and neurodegeneration in Alzheimer's disease. Brain 138:3373-3385. https://doi.org/10.1093/brain/awv26 7

47. Price JL, Davis PB, Morris JC, White DL (1991) The distribution of tangles, plaques and related immunohistochemical markers in healthy aging and Alzheimers-disease. Neurobiol Aging 12:295-312. https://doi.org/10.1016/0197-4580(91)90006-6

48. Reddy PH, Beal MF (2008) Amyloid beta, mitochondrial dysfunction and synaptic damage: implications for cognitive decline in aging and Alzheimer's disease. Trends Mol Med 14:45-53. https ://doi.org/10.1016/j.molmed.2007.12.002

49. Reddy PH, Mani G, Park BS, Jacques J, Murdoch G, Whetsell W Jr et al (2005) Differential loss of synaptic proteins in Alzheimer's disease: implications for synaptic dysfunction. J Alzheimers Dis 7:103-117 (discussion 173-180)

50. Rhoads AR, Friedberg F (1997) Sequence motifs for calmodulin recognition. FASEB J 11:331-340

51. Robinson JL, Molina-Porcel L, Corrada MM, Raible K, Lee EB, Lee VM et al (2014) Perforant path synaptic loss correlates with cognitive impairment and Alzheimer's disease in the oldest-old. Brain 137:2578-2587. https://doi.org/10.1093/brain/awu190

52. Scheff SW, Price DA, Schmitt FA, DeKosky ST, Mufson EJ (2007) Synaptic alterations in CA1 in mild Alzheimer disease and mild cognitive impairment. Neurology 68:1501-1508. https ://doi.org/10.1212/01.wnl.0000260698.46517.8f

53. Scheff SW, Price DA, Schmitt FA, Mufson EJ (2006) Hippocampal synaptic loss in early Alzheimer's disease and mild cognitive impairment. Neurobiol Aging 27:1372-1384. https://doi. org/10.1016/j.neurobiolaging.2005.09.012

54. Serrano-Pozo A, Frosch MP, Masliah E, Hyman BT (2011) Neuropathological alterations in Alzheimer disease. Cold Spring Harb Perspect Med 1:a006189. https://doi.org/10.1101/cshperspec t.a006189

55. Shen J, Kelleher RJ 3rd (2007) The presenilin hypothesis of Alzheimer's disease: evidence for a loss-of-function pathogenic mechanism. Proc Natl Acad Sci USA 104:403-409. https://doi. org/10.1073/pnas.0608332104
56. Spies PE, Slats D, Sjogren JM, Kremer BP, Verhey FR, Rikkert MG et al (2010) The cerebrospinal fluid amyloid beta42/40 ratio in the differentiation of Alzheimer's disease from non-Alzheimer's dementia. Curr Alzheimer Res 7:470-476

57. Spires-Jones TL, Hyman BT (2014) The intersection of amyloid beta and tau at synapses in Alzheimer's disease. Neuron 82:756771. https://doi.org/10.1016/j.neuron.2014.05.004

58. Sze CI, Troncoso JC, Kawas C, Mouton P, Price DL, Martin LJ (1997) Loss of the presynaptic vesicle protein synaptophysin in hippocampus correlates with cognitive decline in Alzheimer disease. J Neuropathol Exp Neurol 56:933-944

59. Tarawneh R, D’Angelo G, Crimmins D, Herries E, Griest T, Fagan $\mathrm{AM}$ et al (2016) Diagnostic and prognostic utility of the synaptic marker neurogranin in Alzheimer disease. JAMA Neurol 73:561-571. https://doi.org/10.1001/jamaneurol.2016.0086

60. Thal DR, Rub U, Orantes M, Braak H (2002) Phases of A betadeposition in the human brain and its relevance for the development of AD. Neurology 58:1791-1800

61. Thorsell A, Bjerke M, Gobom J, Brunhage E, Vanmechelen E, Andreasen $\mathrm{N}$ et al (2010) Neurogranin in cerebrospinal fluid as a marker of synaptic degeneration in Alzheimer's disease. Brain Res 1362:13-22. https://doi.org/10.1016/j.brainres.2010.09.073

62. Wiltfang J, Esselmann H, Bibl M, Hull M, Hampel H, Kessler H et al (2007) Amyloid beta peptide ratio 42/40 but not A beta 42 correlates with phospho-Tau in patients with low- and high-CSF A beta 40 load. J Neurochem 101:1053-1059. https://doi.org/10. $1111 / \mathrm{j} .1471-4159.2006 .04404 . x$

63. Xia ZG, Storm DR (2005) The role of calmodulin as a signal integrator for synaptic plasticity. Nat Rev Neurosci 6:267-276. https://doi.org/10.1038/nrn1647

64. Zakharov VV, Mosevitsky MI (2001) Site-specific calciumdependent proteolysis of neuronal protein GAP-43. Neurosci Res 39:447-453

65. Zhong L, Cherry T, Bies CE, Florence MA, Gerges NZ (2009) Neurogranin enhances synaptic strength through its interaction with calmodulin. EMBO J 28:3027-3039. https://doi.org/10.1038/ emboj.2009.236 